\title{
SIGNS OF EPHREM'S \\ EXEGETICAL TECHNIQUES IN HIS HOMILY ON OUR LORD ${ }^{\dagger}$
}

\author{
ANGELA Y. KIM \\ UNIVERSITY OF NOTRE DAME \\ USA
}

\begin{abstract}
In his Homily on Our Lord, Ephrem employs a number of interpretive techniques to connect Exod 32-4 and Luke 7:36-50 in an essential way. Exod 32-4 and Luke 7 are interwoven through a literal and metaphoric understanding of the word sign which Ephrem introduces by a retelling of a conflated version of the water trial in Exod 32 (Homily, I6). Through typology, Ephrem transforms the golden calf into a proof for the excellence of Christ. The theme of sin and forgiveness that appears in Exod 32 is realized in Christ's transformation of the sinful woman into the paradigmatic Christian.
\end{abstract}

[1] The 59 sections of Ephrem's Homily on Our Lord ${ }^{1}$ are replete with richly woven scriptural images and biblical allusions. The rhetoric

t A version of this paper was read at the Syriac Symposium III: The Aramaic Heritage of Syria, The Summer Syriac Institute, University of Notre Dame, Notre Dame, Indiana, 17-20 June 1999.

${ }^{1}$ The critical edition of this homily is edited by E. Beck, Des Heiligen Ephraem des Syrers Sermo de Domino Nostro, (CSCO 270, 271; Louvain, 1966). See also the English translations by E.G. Mathews, Jr. And J.P. Amar, St. 
of the Homily moves in an elegant circular fashion ${ }^{2}$ between two biblical passages: the golden calf episode (Exod 32-34) ${ }^{3}$ and Christ's encounter with the sinful woman (Luke 7:36-50). While Ephrem's rich scriptural language does not preclude his use of other passages from the Bible, these two texts provide the foci for the Homily and he freely moves between them. Ephrem skillfully alternates from the OT calf in the wilderness to the Gospel story of the sinful woman with an elaborate system of inclusios. Ephrem employs a number of interpretive techniques to scripture. ${ }^{4}$

Ephrem the Syrian, Selected Prose Works (The Fathers of the Church 91; Washington, D.C.: Catholic University of America Press, 1994) 269-332; and A.E. Johnston (trans.), "Homily on Our Lord," The Nicene and Post Nicene Fathers II.13, ed. J. Gwynn (Oxford, 1898) 305-30. English citations of the Homily on Our Lord are adapted from the translation by J.P. Amar (1994).

2 On the use of inclusio by fourth century Syriac writers see R. Murray, Symbols of Church and Kingdom (Cambridge University Press, 1975) 2.

${ }^{3}$ Select studies on the Jewish and Christian history of interpretation of the golden calf episode include L. Smolar and M. Aberbach, "The Golden Calf Episode in Postbiblical Literature, HUCA 36 (1968): 91-116; P.C. Bori, The Golden Calf and the Origins of the anti-Jewish Controversy, trans. by D. Ward, (SFSHJ 16; Atlanta: Scholars Press, 1990) and I.J. Mandelbaum, "Tannaitic Exegesis of the Golden Calf Episode," in P.R. Davies and R.T. White (eds.), A Tribute to Geza Vermes: Essays on Jewrish and Christian Literature and History, (JSOTSup 100; Sheffield: Sheffield Academic Press, 1990) 207-23.

${ }^{4}$ Some formulations of Ephrem's interpretive approach to scripture may be found in R. Murray, Symbols of Cburch and Kingdom, wherein he cites typological parallels and lists of testimonia; idem, "The Theory of Symbolism in St. Ephrem's Theology," Parole de L'Orient 6/7 (1975/76): 1-20; T. Kronholm, Motifs from Genesis 1-11 in the Genuine Hymns of Ephrem the Syrian with Particular Reference to the Influence of Jewish Exegetical Tradition, (CB; Lund Sweden: CWK Gleerup, 1978) and B. de Margerie, "La poésie biblique de Saint Ephrem exégète syrien (306-373)," In Introduction a l'bistoire de l'exégèse: I. Les pères grecs et orientaux (Paris: Les Editions du Cerf, 1980) 179-84, who cites antithetical parallelism, literalism and symbolism as Ephrem's three interpretive rules. Other studies on Ephrem's interpretive techniques include N. el-Khoury, "Hermeneutics in the Works of Ephraim the Syrian," OCA 229 (1987): 93-100; P. Yousif, "Exegetical Principles of St. Ephraem of Nisibis," Studia Patristica 18.4 (1990): 296-302; C. McCarthy, “Allusions and Illusions: St. Ephrem's 
Frequently he presents these two stories as antithetical parallels to one another and he connects them by means of verbal links ${ }^{5}$ or common motifs. In addition to this, Ephrem uses typological exegesis $^{6}$ throughout the Homily. These techniques are used simultaneously, resulting in a complex theological work that is rich in scriptural allusions. In this paper, I will look specifically at Ephrem's Homily on Our Lord, \$6-17, 22-33, 35-43 and his use of the word "sign" ('äta) which theologically and verbally connects the story of the golden calf and the sinful woman in an essential way.

\section{VERBAL LINKS \\ BETWEEN EXODUS 32-34 AND LUKE 7:36-50}

Exod 32-4 and Luke 7:36-50 possess common theological motifs and vocabulary apart from their presence within Ephrem's interpretive work. These mutual motifs and verbal links suggest possible reasons why the Syrian theologian considered these different passages to be suitable material for his prose work on Christ.

Verbal Magic in the Diatessaron Commentary," in K.J. Cathcart and M. Maher (eds.), Targumic and Cognate Studies: Essays in Honour of Martin McNamara, (JSOTSup 230; Sheffield: Sheffield Academic Press, 1996) 187-207.

${ }^{5}$ In the Homily on Our Lord, there are many examples of Ephrem linking different scriptural passages by means of a common word or motif. In \$32, Ephrem establishes a parallel situation between the Old and New Testaments through common names. Saul the first king of Israel becomes analogous to Saul/Paul and David becomes the corollary to the Son of David, namely Jesus. Here Ephrem describes the persecution of David by Saul in light of the persecution of the Christ(ians) by Saul/Paul. A similar joining of different scriptural passages by means of a common word occurs in \$50-8. In this instance, Ephrem compares Simon the priest with Simon Peter the apostle both of whom share the same Syriac name, Shem in. The first Simon received the Christ child in the Temple (Luke 2:25-8) and the second was entrusted with the authority to lead the Church. Together, these two Simons are the antithetical counterpart to Simon the Pharisee in Luke 7:36-50. Examples such as these are plentiful in the Homily and I will not list them in this paper.

${ }^{6}$ de Margerie, "La poésie biblique de Saint Ephrem," 177-9; also see Murray, "Symbolism in St. Ephrem's Theology," 3. 
Exod 32-4 is a pivotal text in the Pentateuch and is viewed as the classic instance of sin in the Israelite history. ${ }^{7}$ Because of this, it also has associations with sin and forgiveness and it is marked by the making, breaking and remaking of the tablets. In a comparable magnitude, the sinful woman associates both sin and forgiveness and she represents the paradigmatic Christian for Ephrem. ${ }^{8}$ Both stories address the forgiveness of sins and share common vocabulary. For example, Luke 7:36-50 is verbally linked to the following italicized words of Exod 32:30, "you have sinned this great sin now, I will go up to the Lord for perhaps he may forgive your debts." The word "sin," (bta $\bar{a})$ is the same root as "sinful woman" (batäytä) in Luke 7:37, 39 and "forgive"(sbaq) also appears in Luke $7: 42,43,47,48$. In addition to this, it should be pointed out that the Peshitta text of Exod 32:30 translates the Hebrew, "your sin" (hata'tkhem) as "your debts" (hawbaykun) thereby allowing for an additional verbal link between the Peshitta and the Lukan text (Luke 7:41, 42).

Theologically, both stories deal with trust and faith. The Israelites pressure Aaron to make a god for them because they are distressed over Moses' absence. Their lack of faith in Moses' return results in apostasy but ultimately, Moses is able to appeal on their behalf. Similarly the Pharisee lacks faith in Christ (Luke 7:39) but the sinful woman's faith saves her.

7 The scandal of the golden calf was so great that Josephus omits it from his history and the rabbis include among the list of forbidden Targumim. See L. Smolar and M. Aberbach, "The Golden Calf Episode in Postbiblical Literature," 92-3, 107-9 and P.S. Alexander, "The Rabbinic Lists of Forbidden Targumim,” JJS 27.2 (1976): 179-80; 183-4; 188-9. The Church viewed the golden calf as the classic example of sin in Israel's history. See Justin, Dialogue. 20:3; 21:1; 22:1; Apostolic Constitutions 6:4:20; Origen, Commentary on Romans 2:14; Lactantius, Divine Institutes 4:10; as cited by L. Smolar and M. Aberbach, "The Golden Calf Episode in Postbiblical Literature," 96.

${ }^{8}$ See the Homily on the Sinful Woman, devoted entirely to Luke 7:3650. Also H.M. Hunt, "The Tears of the Sinful Woman: A Theology of Redemption in the Homilies of St. Ephraim and His Followers," Hugoye 1.2 (1998) and the literature cited there. 


\section{EXODUS 32:25-9: THE INTRODUCTION OF THE SIGN (HOMILY, \$6)}

[5] In addition to these various associations between theological motifs and verbal links between the Peshitta OT and the Lukan text, Ephrem introduces an additional link between the OT calf story and the Gospel story of the sinful woman. While the word sign does not appear in the Peshitta text, it assumes particular importance in Ephrem's Homily insofar as it functions as an essential link between the Old and New Testament stories. In the homily, the word sign is introduced in Ephrem's retelling of Exod 32:25-9 (Homily, \$6).

The golden calf marks a scandalous episode in Israel's history. ${ }^{9}$ Within the context of Exod 32-34, the Israelites craft a golden calf and apostate cult at the very moment that Moses receives the tablets of the covenant and instructions for the wilderness sanctuary. The scandal of the calf is heightened by this juxtaposition of events: at the top of the mountain Moses receives the tablets while at the base of the mountain the Israelites are making their calf. In addition to this orchestration of events, the biblical narrative is filled with inconcinnities and repetition. ${ }^{10}$ Thrice the reader is told of a punishment: first by a water potion (Exod 32:20), second by the slaughter by the Levites (Exod 32: 27-8) and third by a plague (Exod 32:35).

9 Aaron's golden calf episode is tied to the calf cult of Jeroboam. The dependence of Exod 32 on $1 \mathrm{Kgs} 12$ is clear in the incorrect use of the plural, "calves" for Aaron's cult (Exod 32:4). For studies on the tradition history of the golden calf in the Bible see A. Aberbach and L. Smolar, "Aaron, Jeroboam and the Golden Calves," JBL 86 (1967) 129-40 which cites thirteen points of contact between Exod 32 and $1 \mathrm{Kgs}$ 12:25ff. More recently, see G.N. Knoppers, "Aaron's Calf and Jeroboam's Calves," in A.B. Beck et al. (ed.), Fortunate the Eyes that See: Essays in Honor of David Noel Freedman in Celebration of his Seventieth Birthday (Grand Rapids, MI: Eerdmans, 1995) 92-104.

${ }^{10}$ For a general survey of the internal inconsistencies in form and content of Exod 32 see B. Childs, The Book of Exodus: A Critical, Theological Commentary, (OTL; Louisville: Westminster Press, 1974) and H.C. Brichto, "The Worship of the Golden Calf: A Literary Analysis of a Fable on Idolatry," HUCA 54 (1983): 1-44. 
Exegesis and interpretation arise from problematic features that are perceived to be present in the text. ${ }^{11}$ The multiple punishment scenes in Exod 32 may have been viewed as a problematic feature that in turn generated various interpretations. One attempt to address the problem of the multiple punishment scenes conflates the first two (Exod 32:20 and 32:27-28) by means of an external text. This type of exegesis (gezerah shavab) clarifies the ambiguous Hebrew word pära ("unbound" or "unrestrained") in Exod 32:25 by introducing an unrelated text that also contains that word, namely Num 5:18. The water trial of the adulteress in Num 5:18 is then used to interpret the unrestrained people in Exod 32:25. In both instances, the water potion effects a sign of guilt upon the one who is charged with a crime. Targum Ps. Jonathan is one example of this type of exegesis. It reads as follows:

He took the calf that they had made and burned (it) in the fire; he ground (it) until it was powder, scattered (it) on the surface of the water of the brook, and made the children of Israel drink (it). Whoever had given an object of gold there, a mark came out on his face (Ps.Jon 32:20).

A few lines later, the Targum goes on to state:

The sons of Levi did according to the word of Moses, and that day, of the people who had the mark on their faces, there fell, slain by the sword, about the number of three thousand men (Ps.Jon 32:28).

The conflation of the water potion (Exod 32:19-20) with the slaughter by the Levites (Exod 32:25-9) by means of Num 5:18 is also attested in Pirkê de Rabbi Eliezer $45 .{ }^{12}$

${ }^{11}$ G. Vermes, "Bible and Midrash: Early Old Testament Exegesis," in Post-Biblical Jewish Studies (Studies in Judaism in Late Antiquity 8; Leiden: E.J. Brill, 1975) 62.

12 The relevant passage from Pirkê de Rabbi Eliezer 45 reads as follows: "He made Israel drink the water (with the dust of the calf). Everyone who had kissed the calf with all his heart, his upper lip and his bones became golden, and the tribe of Levi slew him, until there fell of Israel about three thousand men." See G. Friedlander's translation in Pirkê de Rabbi Eliezer: The Chapters of Rabbi Eliezer the Great According to the Text of the Manuscript Belonging to Abraham Epstein of Vienna (New York: Hermon Press, 1965) 356-7. See also L. Smolar and M. Aberbach, "The Golden Calf Episode 
While both Targum Ps. Jonathan and Pirkê de Rabbi Eliezer are much later than Ephrem, he relies upon a similar kind of exegetical tradition in his retelling of Exod 32:25-9 insofar as the word sign plays a key role in his version of events. Like the Targum, Ephrem understands the sign as an external mark of an interior state of adulterous guilt. The external sign is literally the distinguishing factor between the guilty and the innocent. The relevant section from the Homily reads as follows:

The sons of Levi became avengers in the open: (Moses) placed a sign on the offenders to make it easy for the avengers to avenge. The drink of the calf entered those in whom the love of the calf was dwelling and left a clear sign on them, so that the drawn sword could assail them. (Moses) gave the waters of testing to the synagogue that had fornicated with the calf, so that the sign of the adulteress would appear on it. This is where the law comes from concerning women drinking the waters of testing, so that, in the sign which appeared on the adulteresses, the synagogue would recall its fornication with the calf, and with fear be on guard against another (fornication), and with regret remember the first one (Homily, $\$ 6)$.

It seems clear that Ephrem chooses to use this conflated exegetical tradition over the account found in the Peshitta. In his Commentary on Exodus, he abides by the standard biblical sequence of events found in the Peshitta. ${ }^{13}$ Ephrem would not have been

in Postbiblical Literature," $102-3$ and their reference to the T.B. Avodah Zarah 44a.

${ }^{13}$ While poorly preserved at this juncture, the relevant section from Ephrem's Commentary on Exodus reads as follows: "Only those who originated (the idea) in their minds, and then encouraged the others, were made to drink the dust. (Moses) said to Aaron: 'What has this people done to you that you should lead them into so serious a sin?' He did not (say): 'You led them into sin. ...' Moses stood at the entrance of the camp, and said: 'Whoever is for the Lord, let him come to me.' The sons of Levi gathered (around him). He said to them: Thus says the Lord: 'Let every man put his sword on his hip.' The Lord did not say to him ... before he relented. When (the Lord) was convinced by him, (Moses) said: 'the Lord relented from the punishment He said He would inflict on the people.' At the top (of the mountain) stood the intercessor, and at the bottom of the mountain, the avenger. Faced with justice ... mercy. And in the camp 
able to make the exegetical link with Num 5 from the Peshitta text alone because the Peshitta does not translate the Hebrew para $^{e}$ ("unrestrained") stereotypically, but rather contextually. Peshitta Exod 32:25 reads, "Moses saw that the people sinned, that Aaron made them sin," in contrast to the Hebrew MT which reads, "Moses saw that the people were unrestrained because Aaron unrestrained (them)." The Peshitta contextually translates the ambiguous Hebrew root, pāra with a form of the Syriac word, bța thereby breaking any connection with Num 5:18. In the Homily on Our Lord, Ephrem seems to be relying upon an exegetical tradition that is similar to the one found in Targum Ps. Jonathan.

While Ephrem frequently refers to material that is common in the Aramaic Targums, ${ }^{14}$ there are two possible reasons why the conflated version may have been more appealing to him for the Homily. The first may be due to the richer theological motifs that the conflated version provides. The conflation of Exod 32:25-9 with Num 5:18 provides a convenient transition to his treatment of Luke 7:36-50 since both texts center around women who have a questionable status in society. The second reason deals with the word sign itself. It is possible that Ephrem preferred the conflated version of Exod 32:25-9 on account of the prominence of the word sign. Later in the Homily, the word sign functions as an important interpretive element in Ephrem's discussion of the Pharisee in Luke 7:36-50.

\section{Christological Transformation of THE SigN (HoMILY, \$6-17A)}

[11] In the original context of Num 5:16-28, the absence of a sign is proof of her innocence and the presence of a sign determines her guilt. Similarly, in the conflated interpretations of Exod 32:25-9 (best seen in the Aramaic Targum) and in Ephrem's retelling of the

(stood) one who was anxious to discipline ... the command of God...” and here the text ends (as translated by J. Amar and E.G. Mathews, Jr. 1994).

${ }^{14}$ On the preference for Jewish Aramaic Targum traditions over the Peshitta, see S. Brock, "Jewish Traditions in Syriac Sources," JJS 30 (1979): 212-32, reprinted 1992. On the relationship between Palestinian Targums and Syriac, see more recently, idem., "A Palestinian Targum Feature in Syriac," JJS 46 (1995): 274, 276, esp. 279-80 for reference to the relationship between Ephrem and Jewish Palestinian Targums. Also see the literature cited by T. Kronholm in Motifs from Genesis 1-11. 
calf story in Homily, $\$ 6$, it is the disclosure of a sign that implies guilt. Ephrem then reverses this schema by describing how Christ transforms the notion that the visibility of a sign is a true and accurate indicator of guilt or innocence. Picking up on the literal understanding of sign as an external sign of an interior state, Ephrem writes the following concerning circumcision:

In your own flesh you removed the external sign of circumcision, according to which the uncircumcised who were yours were not considered to be yours. Then you removed (the external sign), but you introduced (as) your sign, the circumcision of the heart, by which the circumcised were recognized as not being yours. For you came to your own, but your own did not accept you (Homily, \$7).

In this excerpt, Ephrem appeals to Pauline theology. The mere presence of the external sign of circumcision is not an accurate indicator of belief. The external and visible sign of circumcision that once distinguished God's special people from the other nations is replaced by its antithesis, the invisible sign of circumcision of the heart. This invisible sign now distinguishes true believers from non-believers. In this section, Ephrem effects the transformation of the external sign for it is no longer the case that the external sign is an arbiter between the faithful and the unfaithful.

Ephrem continues to discuss signs in his christological excursus (Homily, §9-13). Here, Ephrem writes that the true signs that effect belief and faith are the Incarnation and Christ's restorative powers for healing. He displays his command of scripture by writing, "The prophets worked all (sorts of) signs, but nowhere (is it recorded that) they filled up a deficiency in the parts of the body," (Homily, \$12). Healing is truly the greatest sign, i.e. testimony, of Christ's power. Within this christological excursus, Ephrem writes about Christ's healing of the deaf-mute. These restorative powers are theologically linked to Christ's creative power, which is described in terms of the Incarnation and the creation of Adam. ${ }^{15}$ However, Ephrem also links the christological excursus to the Luke 7 passage through a reference to a text that is

${ }^{15}$ Ephrem's reference to the "Architect of the body" in Homily, $\$ 10$, is probably an intentional link to the creation passage in Proverbs 8:22. 
adjacent to the Gospel story of the sinful woman, namely, the healing of the woman with the flow of blood (Luke 8:43-8). The most persuasive testimony or sign, in Ephrem's opinion, is the healing and restorative power of Christ, the Medicine of Life. In this way, Ephrem establishes the link between the Gospel story of the sinful woman with the healing story from Luke 8:43-8 because healing is one of the great signs of Christ's reign. Just as the conflated Aramaic Targum version of Exod 32:25-9 is connected by an external text about an adulterous woman, (Num 5:18), the NT story of the sinful woman is connected to the Homily by means of an external text about a woman (Luke 8:43-8). ${ }^{16}$

That Christ alone is capable of this healing power is proof that Christ is greater than the prophets. This anticipates the Pharisee's criticism in Luke 7:39, "If this man were a prophet, he would have known who and what kind of woman this is." For Ephrem it is clear that the Pharisee's criticism is misdirected from the very beginning for the Pharisee is concerned with the wrong type of sign. Ephrem writes:

Simon the Pharisee had welcomed our Lord as a prophet on account of the signs (he had performed), not because of faith. For he was a son of Israel, who, when signs approached, likewise approached the Lord of the signs. But when signs ceased, there he stood, naked and without faith. This man also thought our Lord was a prophet when he saw signs accompany Him. But when our Lord stopped (performing) signs, (the Pharisee) was overcome with the doubt of his countrymen: "If this man were a prophet, he would know that this woman is a sinner" (Homily, \$16).

In Ephrem's version of the golden calf (Homily, $\$ 6$ ), the presence of the guilty sign of the adulteress identified the unfaithful idolaters. In the New Testament, the opposite is the case insofar as the absence of signs reveals those who have little faith.

Ephrem then constructs an antithetical parallel between Christ and the calf in order to illustrate the misguided faith of the Pharisee in the Lukan story. In his initial discussion of the calf Ephrem

${ }^{16}$ H.M. Hunt ("The Tears of the Sinful Woman," par. 13) writes that in Ephrem's Commentary on the Diatessaron, part 5, section 7, both the hemorrhaging woman and the sinful woman see Jesus with "a physical manifestation of an inner need for healing." 
writes the following: "dead idols with closed mouths fed on the life of their worshippers ... a single calf which they fashioned in the wilderness fed on their lives, as though on grass in the wilderness" (Homily, \5,6). The calf's inability to eat is proof that idolatry is not able to lead people to true nourishment, namely everlasting life. As it is written in Exod 32:20, the golden calf was burnt, ground into a powder and strewn into the water for the Israelites to drink. According to the conflated account used by Ephrem, this potion of the idolatrous calf effected a sign for death by the Levites. Ephrem contrasts the golden calf that cannot eat with Christ who is able to nourish and heal. ${ }^{17}$ In the christological excursus, Ephrem describes the healing of the deaf-mute (Homily, §10b-13). Immediately following, Ephrem constructs a parallel between Christ's saliva and the yeast for the Eucharistic bread. Unlike the calf that brings death, Christ's presence in the Eucharist gives life. In this way Ephrem presents the golden calf that neither eats nor nourishes as the antithesis to Christ whose presence in the Eucharist gives life.

\section{The Typology of THE Golden CALF}

[15] Ephrem creates a typological relationship between the golden calf and Simon the Pharisee. The golden calf's inability to eat and live is further reinforced by Ephrem's citation from Ps 115:5-6, "they have eyes but do not see, and ears but do not hear." While he only cites vv. 5-6 of Ps 115 in Homily, $\$ 8$, the Psalm continues with, "those who make them are like them; so are all those who trust in them" (Ps. 115:8). Later Ephrem draws the Pharisee into his antithetical parallel between the golden calf who cannot eat and Christ who truly nourishes. Ephrem writes,

Now the Pharisee had made elaborate preparations for our Lord at his banquet, while the sinful woman did simple things for Him there. For all his elaborate fare, the Pharisee only let our Lord taste the feebleness of his love. But with her tears, the sinful woman let our Lord taste her abundant love. The one who had invited him to a grand banquet was chastised because of his

17 See Smolar and Aberbach, "The Golden Calf Episode in Postbiblical Literature," 100-1 and their reference to Augustine's sacramental interpretation of the golden calf. 
feeble love, while (the sinful woman) blotted out the great bond of her debt with her meager tears (Homily, \$16).

Thus Simon the Pharisee falls under the typology of the golden calf for he cannot provide Jesus with true nourishment at his dinner. In a similar vein, Simon the Pharisee falls under the typology of the false worshippers who created the golden calf in the wilderness. In Ephrem's description of Simon the Pharisee in the Gospel story (Luke 7, Homily, \$16), he writes about the limited efficacy of physical signs for the Pharisee's belief is said to rely solely upon their presence. Ephrem writes, "But when our Lord stopped the signs, (the Pharisee) was overcome with the doubt of his countrymen." Just as the Israelites had erred by worshipping a golden calf in the wilderness, Simon the Pharisee is marked by his trust in physical signs.

\section{THEOPHANY (HOMILY, \$22-33)}

[16] The use of the word sign continues to be a distinguishing element in Ephrem's exegesis of Moses' theophany at Sinai (Exod 33:1723; 34:33-35) and Paul's theophany on the road to Damascus (Acts 9) in Homily, $\$ 22-33$. On one level, this part of the homily ( $\$ 22-$ $33)$, centers on the virtue of humility ${ }^{18}$ and attempts to explain why Jesus responds to the bold questioning of the Pharisee in Luke 7 with a parable and not with a stiff reprimand (Homily, \$22). On a different level, these sections are an expansion of Ephrem's words about the sinful woman herself, "Our Lord worked wonders with common things so that we would know of what those who scorn wonders are deprived" (Homily, \$14). In other words, Christ, who is capable of magnanimous signs, namely the Incarnation and restorative healing (Homily, \$10b-13), ironically presents the paradigmatic Christian (the sinful woman) in a simple and humble manner. Ephrem writes, "the Pharisee was unconvinced by the wondrous signs he saw, so He came to him to convince him with humble tones" (Homily, \$42).

The sinful woman who lies prostrate before Christ in her posture of repentance is also an allusion to Saul who falls to the

18 Ephrem's exaltation of humility in the face of bold questioning probably is generated by 2 Cor 10-3 and Paul's words that "power is made perfect in weakness" (2 Cor 12:9). 
ground upon seeing the divine light (Acts 9:4). Unlike the Pharisee who doubts Christ, the woman recognizes the theophany before her. In this section, Ephrem points that Paul's blindness ironically led to his ability to see. With similar irony, Moses is granted the opportunity to see the glory of YHWH but then conceals it from the Israelites with a veil. Ephrem writes,

Even though the eyes of Moses were physical, like those of Paul, his interior eyes were Christian. For "Moses wrote concerning me..." In the case of Paul, his exterior eyes were as open as those within were closed. The exterior eyes of Moses radiated because his interior eyes saw clearly. Paul's exterior eyes were kept closed, so that by the closing of his exterior eyes those within would be open. He who had been unable to perceive our Lord through His signs with exterior eyes, perceived Him with interior eyes once his physical (eyes) were closed. And because he took an example from his own experience, he wrote to those whose bodily eyes saw clearly: "May he enlighten the eyes of your hearts." So visible signs in no way helped the exterior eyes of the Jews; faith of the heart opened the eyes of the hearts of the nations.

If Moses simply had come down from the mountain without his face radiating, and had said, "I saw the radiance of God there," the infidel fathers would not have believed him. And likewise with Paul: the crucifying sons would not have put faith in him if his eyes had not been injured, and he had said, "I heard the voice of Christ." This is why, as though out of love, (God) set a desirable sign of radiance on Moses in order to convince them that (Moses) had seen the divine radiance. But on Saul, as on a persecutor, He set the infamous sign of blindness so that the liars would believe that he had heard the words of Christ.

(Homily, \$32).

Ephrem goes on to write that the Israelites fail to recognize the visible signs on their bodies and their clothes. The visible signs and transformations that God provides are ineffectual at persuading the Israelites of the wrong of their ways.

[19] In the passage cited above, Ephrem makes an allusion to his retelling of Exod 32:25 (Homily, \$6) in which the sign of the adulteress is a visible sign of guilt. "Out of love, (God) set a 
desirable sign of radiance on Moses... but on Saul, as on a persecutor, he set the infamous sign of blindness." The external sign corresponds to the interior state of the branded individuals. In the case of the Israelites, the sign is a guilty sign of the adulteresses because the calf was an act of infidelity. In the case of Moses, the sign refers to a state of grace because he was granted a vision of the glory of YHWH. For Saul the external sign is one of blindness. The implication is that it is only through interior vision that one comes to know Christ, not through physical sight and physical signs.

Here, Ephrem reveals the complexity of his understanding of sign. The word sign is no longer used in a metaphoric sense, as in a sign on the heart (Homily, \$7), but rather in a literal and visible way. In effect, Ephrem recapitulates to the literal understanding of the sign from his conflated retelling of Exod 32:20-9 (Homily, \$6) wherein the external visibility of the sign plays an important role in distinguishing between people. Ephrem has transformed the visible sign of guilt into a visible sign of grace.

\section{Some Concluding Comments}

[21] Ephrem employs a number of interpretive techniques to connect Exod 32-4 and Luke 7:36-50 in his Homily on Our Lord. In this paper, I suggested that Ephrem uses the word sign to connect these two passages in a complex system of inclusios. While both texts share the theme of sin and forgiveness, one text is the classic example of sin and the other is a paradigm for repentance. The stories of the golden calf and the sinful woman are interwoven through the use of the word sign which Ephrem introduces in his conflated account of Exod 32 and Num 5 (Homily, \$6).

The typology of the golden calf is one way in which Ephrem reflects upon Christ for the golden calf is the antithesis of Christ. In Ephrem's discussion of the golden calf (Homily, \$6) and the theophany (Homily, \$32), the word sign functions in an essential way. The literal and the metaphoric understanding of the word sign plays an important role in illustrating the central theological theme of the homily, namely Christ's transformative power. This central theme is established in the opening line of the Homily, "Goodness encountered slandering mouths and made them into praising harps" and demonstrated in Christ's transformation of the sinful woman into the paradigmatic Christian (Luke 7:36-50). Similarly, 
Ephrem transforms the base golden calf into part of his proof for the excellence of Christ in his Homily on Our Lord.

\section{BIBLIOGRAPHY}

Aberbach, A., and L. Smolar. "Aaron, Jeroboam and the Golden Calves." JBL 86 (1967): 129-40.

Alexander, P.S. “The Rabbinic Lists of Forbidden Targummim.” JJS 27.2 (1976): 177-91.

Beck, E., ed. Des Heiligen Ephraem des Syrers Sermo de Domino Nostro. CSCO, 270, 271. Louvain, 1966.

Bori, P.C. The Golden Calf and the Origins of the anti-Jewish Controversy. Trans. by D. Ward. SFSHJ, 16. Atlanta: Scholars Press, 1990.

Brichto, H.C. "The Worship of the Golden Calf: A Literary Analysis of a Fable on Idolatry." HUCA 54 (1983): 1-44.

Brock, S.P. "Jewish Traditions in Syriac Sources." JJS 30 (1979): 212-32, reprinted 1992.

Brock, S.P. "A Palestinian Targum Feature in Syriac." JJS 46 (1995): 27182.

Childs, B.S. The Book of Exodus: A Critical, Theological Commentary. OTL. Louisville, KY: Westminster Press, 1974.

Friedlander, G., trans. Pirkê de Rabbi Eliezer: The Chapters of Rabbi Eliezer the Great According to the Text of the Manuscript Belonging to Abrabam Ephstein of Vienna. New York: Hermon Press, 1965.

Hunt, H.M. "The Tears of the Sinful Woman: A Theology of Redemption in the Homilies of St. Ephraim and His Followers." Hugoye 1.2 (1998).

Johnston, A.E., trans. "Homily on Our Lord." The Nicene and Post Nicene Fathers Series II. Vol. 13. Ed. by J. Gwynn. Oxford, 1898. Reprinted by Grand Rapids, MI: Wm. B. Eerdmans, 1979: 30530.

el-Khoury, N. "Hermeneutics in the Works of Ephraim the Syrian." OCA 229 (1987): 93-100.

Knoppers, G.N. “Aaron's Calf and Jeroboam's Calves.” In Beck, A.B., et al., ed. Fortunate the Eyes that See: Essays in Honor of David Noel Freedman in Celebration of his Seventieth Birthday, 92-104. Grand Rapids, MI: Eerdmans, 1995.

Kronholm, T. Motifs from Genesis 1-11 in the Genuine Hymns of Ephrem the Syrian with Particular Reference to the Influence of Jewish Exegetical Tradition. CB. Lund: CWK Gleerup, 1978.

Mandelbaum, I.J. "Tannaitic Exegesis of the Golden Calf Episode." In Davies, P.R., and R.T. White. A Tribute to Geza Vermes: Essays on Jewish and Christian Literature and History, 207-233. JSOTSup, 100. Sheffield: Sheffield Academic Press, 1990. 
Margerie, Bertrand de. "La poésie biblique de Saint Ephrem exégète Syrien (306-373)." In Introduction a l'bistoire de l'exégèse: I. Les pères grecs et orientaux, 165-87. Paris, Les Éditions du Cerf, 1980.

Mathews, E.G., Jr., and J.P. Amar, eds. St. Ephrem the Syrian, Selected Prose Works. The Fathers of the Church, 91, ed. by K. McVey. Washington, D. C.: Catholic University of America Press, 1994.

McCarthy, C. "Allusions and Illusions: St. Ephrem's Verbal Magic in the Diatessaron Commentary." In Cathcart, K.J., and M. Maher, eds. Targumic and Cognate Studies: Essays in Honour of Martin McNamara, 187-207. JSOTSup, 230. Sheffield: Sheffield Academic Press, 1996.

Murray, R. Symbols of Church and Kingdom. Cambridge University Press, 1975.

—. "The Theory of Symbolism in St. Ephrem's Theology." Parole de L'Orient 6/7 (1975/6): 1-20.

Smolar, L. and M. Aberbach. "The Golden Calf Episode in Postbiblical Literature." HUCA 36 (1968): 91-116.

Vermes, G. "Bible and Midrash: Early Old Testament Exegesis." In PostBiblical Jewish Studies, 59-91. Studies in Judaism in Late Antiquity, 8. Leiden: E. J. Brill, 1975.

Yousif, P. "Exegetical Principles of St. Ephraem of Nisibis." Studia Patristica 18:4 (1990): 296-302. 